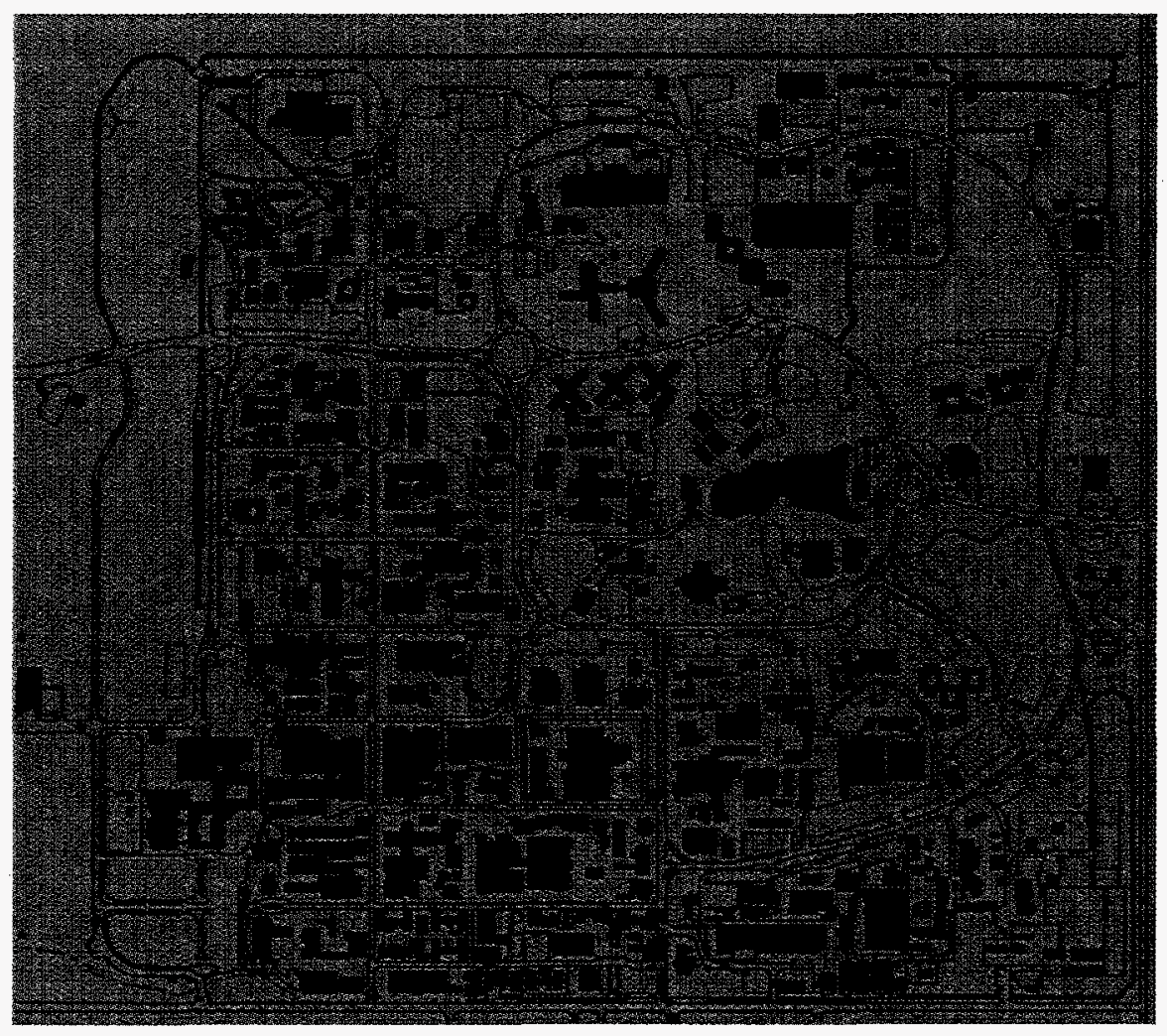

\title{
LLNL Line-Item Construction Projects Master Site Plan
}

April 15, 1996

SSP-96-0086-PC

Lawrence Livermore National Laboratory

Plant Engineering/Space \& Site Planning 
This document was prepared as an account of work sponsored by an agency of the United States Government. Neither the United States Government nor the University of California nor any of their employees makes any warranty, express or implied, or assumes any legal liability or responsibility for the accuracy, completeness, or usefulness of any information, apparatus, product, or process disclosed, or represents that its use would not infringe privately owned rights. Reference herein to any specific commercial products, process, or service by trade name, trademark, manufacturer, or otherwise, does not necessarily constitute or imply its endorsement, recommendation, or favoring by the United States Government or the University of California. The views and opinions of authors expressed herein do not necessarily state or reflect those of the United States Government or the University of California and shall not be used for advertising or product endorsement purposes.

Work performed under the auspices of U.S. Department of Energy by Lawrence Livermore National Laboratory under Contract No. W-7405-Eng-48.

This report has been reproduced directly from the best available copy.

Available to DOE and DOE contractors from the Office of Scientific and Technical Information

P.O. Box 62, Oak Ridge, TN 37831

Prices available from (615) 576-8401, FTS 626-8401

Available to the public from the

National Technical information Service

U.S. Department of Commerce

5285 Port Royal Rd., Springtield, VA 22161 
In compliance with the new DOE Life Cycle Asset Management (LCAM) Order, the LLNL Comprehensive Site Plan is under way, incorporating stakeholders involvement into the Laboratory's formal site development planning process.

The interim submittal presented here is an updated 1996 overview of the Master Plan based on the 1995 LLNL Site Development Plan, illustrating the future land use considerations, and the locations of proposed facilities as documented through the line item development process (see figure 1), and keyed to the summary Table-A.

The Laboratory's current comprehensive planning process is a collaborative effort between Programmatic Directorates, the Operations Directorate and the Directors Office. This effort requires coordination, analysis, and integration of various planning elements including program mission projection and requirements, institutional priorities, security, hazards, utilities and operations.

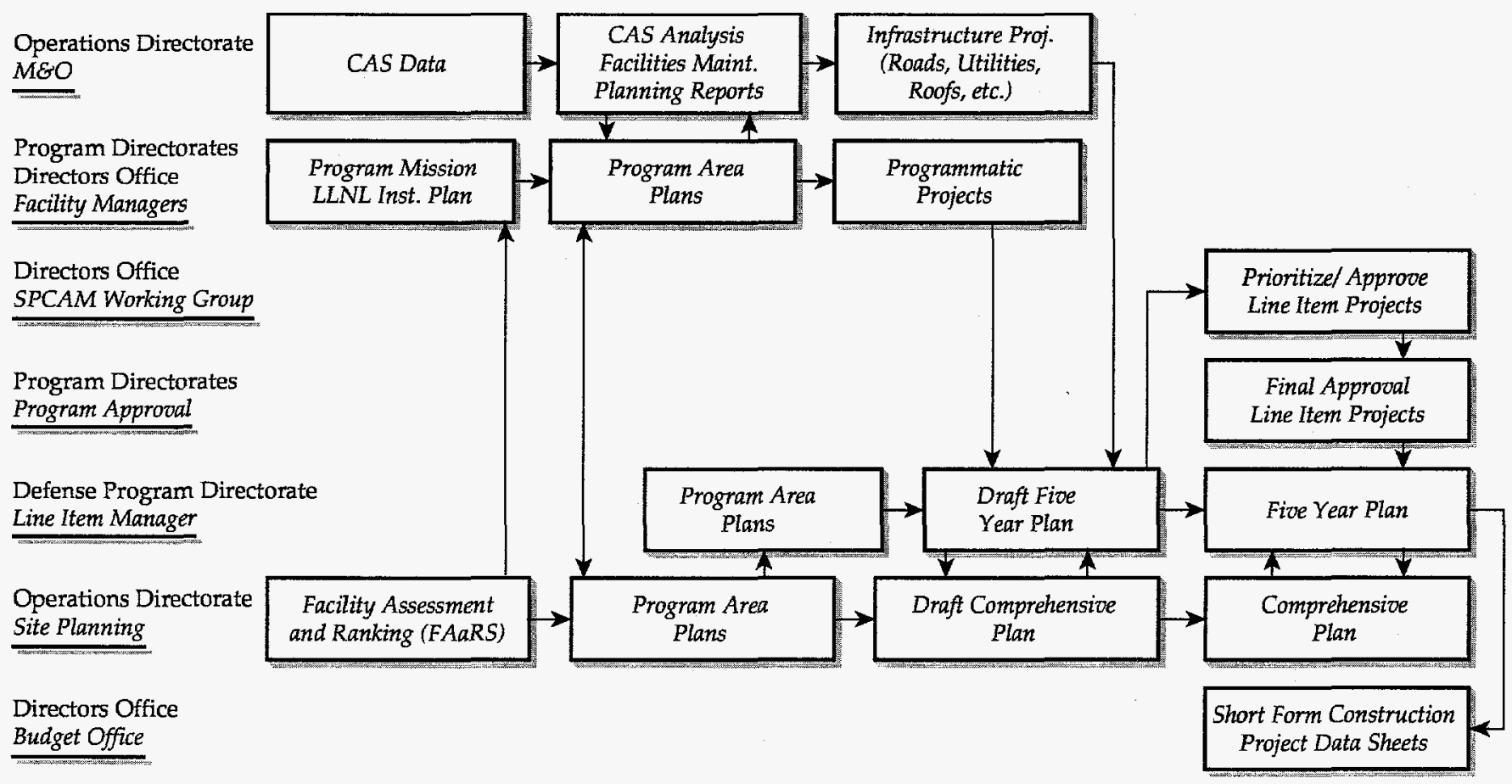

Figure 1. Line-item Development Process at LLNL.

As elaborated in last year's Site Development Plan, the following components in addition to the Line-Item proposals remain the key elements in the implementation strategy of the Master Plan.

Personnel Migration: Completion of the B132 Complex (DPRF \& NTTC) and B170 (National Atmospheric Release Advisory Center) will result in collocation of various programmatic organizations. The activation of B132 will also create opportunities to dispose of temporary and substandard facilities after judicious backfill of vacated space. Areas will be redeveloped in a coordinated effort with facility management to optimize space utilization and operation efficiencies.

Revitalization: Due to nominal amount of new facility construction anticipated, workforce migrations and site redevelopment are significant in shaping the future of the site. An integral part of development is renovating suitable facilities for adaptive reuse. The Defense Program is currently exploring possibilities in the revitalization of facilities and the infrastructure; results will affect subsequent line-item proposals.

Space Reduction: Substandard facilities not suitable for renewal will continue to be targeted for scheduled removal to reduce the maintenance backlog burden, allowing resources to be focused on mission essential facilities.

Classified Core Contraction: Reducing the size of the fenced compound dedicated to classified research will be accomplished by a phased approach. Increased site accessibility will reduce operational costs, improve facility utilization and facilitate collaboration interface with private/industrial/academic sectors. 
Utility Systems: Completion of a looped utility network to improve service and reliability for programmatic support remains an important site development objective. The site-wide evacuation paging system upgrade is a continuing project to improve emergency communication. Emphasis on other system upgrades are the Fiber Optics

Communication Backbone Project and the Storm Drain/Sewer System Rehabilitation Project.

Environmental Restoration: The long term ground water cleanup program will continue with characterization of the site and deployment of effective treatment facilities for remediation.

In addition, General Plant (GP) projects are proposed as required, which include capital equipment and capital improvements with the ancillary demolition.

Table -A. LINE-ITEM CONSTRUCTION PLAN PROJECT SUMMARY

\begin{tabular}{|c|c|c|c|c|}
\hline $\begin{array}{l}\text { Project } \\
\text { Key }\end{array}$ & Sponsor & Project & $\begin{array}{l}\text { FY } \\
\text { Start }\end{array}$ & $\begin{array}{r}\$ M \\
T E C\end{array}$ \\
\hline \multicolumn{5}{|c|}{ Funded Projects } \\
\hline 1 & $\mathrm{DP}$ & Nuclear Test Technology Complex (NTTC) & 88 & 64.6 \\
\hline 2 & EM & Decontam./Waste Treatment Facility & 89 & 68.0 \\
\hline 3 & $\mathrm{DP}$ & Defense Programs Research Facility (DPRF) & 91 & 72.6 \\
\hline- & $\mathrm{DP}$ & Electrical Power Replacement/Upgrade I & 91 & 31.0 \\
\hline- & $\mathrm{DP}$ & Fiber Optics Comm. Backbone & 91 & 1.8 \\
\hline- & $\mathrm{DP}$ & Infrastructure Modernization & 92 & 11.1 \\
\hline - & $\mathrm{EM}$ & Sanitary Sewer Rehabilitation & 92 & 7.1 \\
\hline - & $\mathrm{EM}$ & Tank Upgrades Project & 92 & 9.54 \\
\hline 4 & $\mathrm{DP}$ & National Atmospheric Release Advisory Center & 93 & 11.3 \\
\hline 5 & $\mathrm{DP}$ & National Ignition Facility & 96 & $842.6^{*}$ \\
\hline
\end{tabular}

$\begin{array}{rlllr}\text { Proposed Projects } & & & \\ - & \text { DP } & \text { Protection of Real Property (roofs) Phase I } & 97 & 7.8 \\ 6 & \text { ER } & \text { Genomics \& Structural Biology } & 99 & 39.9 \\ - & \text { DP } & \text { Alternate Refrigerant Conversion } & 99 & 9.3 \\ - & \text { DP } & \text { Protection of Real Property (roofs) Phase II } & 99 & 8.9 \\ - & \text { DP } & \text { Road Construction } & 99 & 7.8 \\ - & \text { DP } & \text { Storm Drain/Sewer System Rehabilitation } & 99 & 7.6 \\ 7 & \text { DP } & \text { B151 Plant and Seismic Upgrade } & 99 & 11.5 \\ 8 & \text { DP } & \text { B511 Rehabilitation } & 99 & 8.0 \\ 9 & \text { DP } & \text { B431 Adaptive Re-Use Project } & 00 & 33.0 \\ 10 & \text { ER } & \text { B543 Addition } & 00 & 18.2 \\ 11 & \text { DP } & \text { NW Low Conductivity Water (LCW) Station } & 00 & 6.5 \\ - & \text { DP } & \text { Protection of real Property (roofs) Phase III } & 01 & 8.3 \\ - & \text { DP } & \text { Tank Upgrades Project II } & 01 & 5.1 \\ 12 & \text { ER } & \text { Energy Program Office Building } & 01 & 20.4 \\ 13 & \text { EM } & \text { B222 Chem. Bldg. Decon/Demolition } & 01 & 23.2 \\ 14 & \text { DP } & \text { B321 General Upgrade } & 01 & 11.0\end{array}$

- indicates site-wide projects.

Projects keyed to Master Site Plan on opposite page.

TEC is Total Estimated Cost (over the life of project)

*Additional \$26M will be required for support facilities if LLNL Site is selected. 


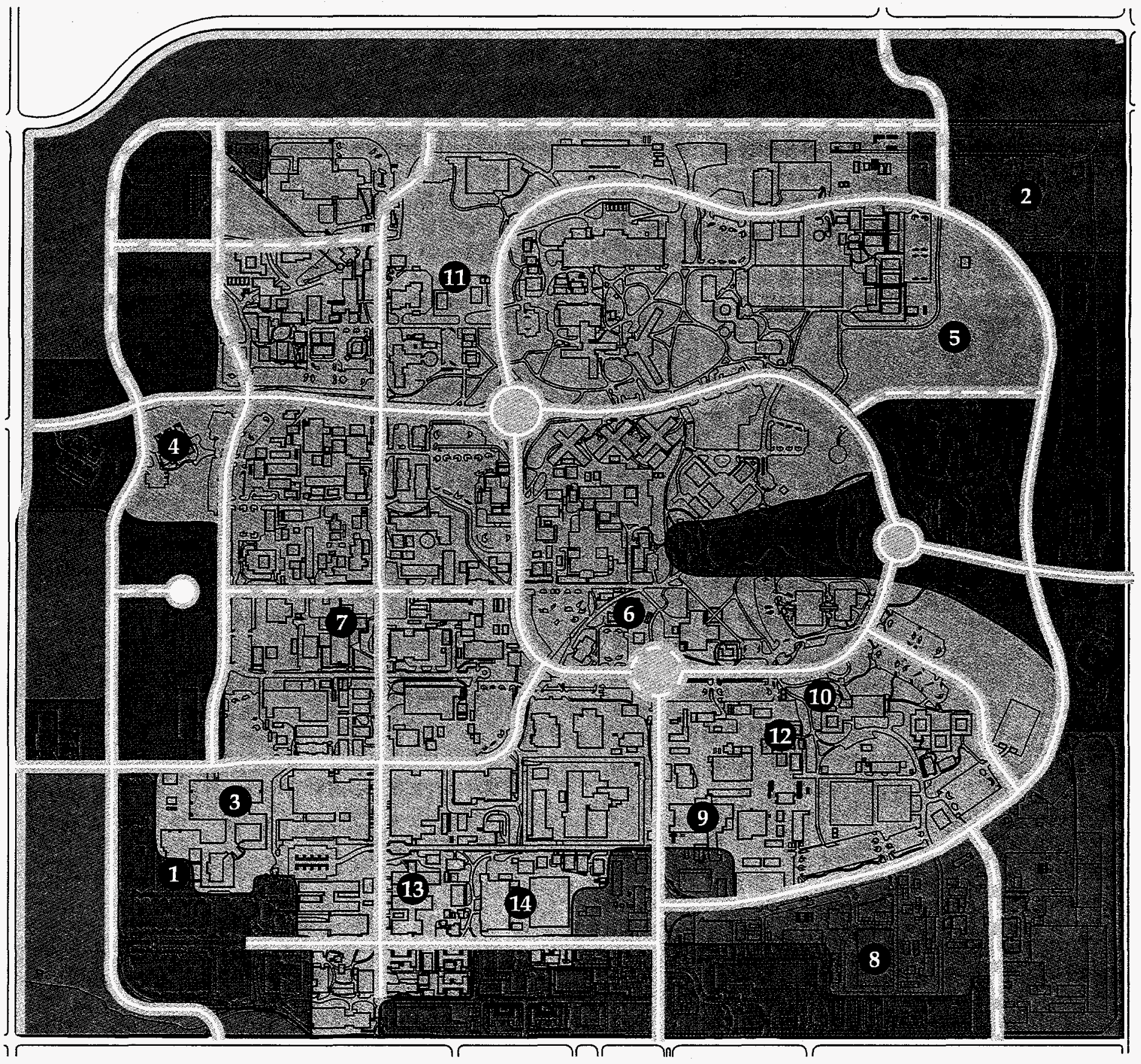

Land Use Legend

Industrial: Warehouses, open storage, maintenance shops, and waste management corporation yards.

Institutional (public and quasi-public facilities and collaborative): Clinics, cafeterias, conference centers, visitor centers, and badge offices; mixed-use facilities providing collaborative research opportunities with other institutions and industry, scientific research office facilities and computational laboratories.

Research \& Development and Administrative/ Technical Support: Office facilities, light and heavy laboratories, and light industrial facilities in support of programmatic endeavors; office facilities used primarily to house the Laboratory professional service and technical support staffs.

Undeveloped: Undeveloped property, including floodplains and buffer zones, open space, and active/passive outdoor recreational areas.

Easements \& Utility Rights-of-Way

Proposed Roadway Extensions

Figure 2. Future Land Use/Master Plan Map. 
The following components are the key elements in the implementation strategy of the Master Plan for Site 300.

Site 300 Development goals:

- Preserve and extend the capability to safely test explosives while protecting the environment.

- Build facilities to provide improved safety features and enhance technical capabilities.

- Foster and promote the viability of Site 300 as an experimental test location.

- Prepare to assume responsibility for limited HE production pursuant to LLNL's stockpile stewardship mission, and reconfiguration of the DOE weapons complex.

Facility Upgrades: Facility and infrastructure upgrades such as fire suppression, communication, and electrical power distribution systems must be pursued to provide efficient, modern and code compliant facilities capable of handling emergency events. Upgrading of existing process facilities would provide limited production capability as necessary to maintain the current weapons stockpile.

Ecosystem Management: Testing of all weapons components at Site 300 must be done in an environmentally acceptable manner. The Site 300 environmental restoration project includes ongoing remedial investigations, feasibility studies, and remedial actions, conducted under joint oversight and the authority of a Federal Facility Compliance Agreement.

Security: The 1993 physical security reconfiguration greatly reduced Limited Security Areas creating Limited Security "islands," leaving the rest of the site a Controlled Area during normal working hours. Most of the site is now accessible to a far greater number of potential users.

Infrastructure: The facilities revitalization project has resulted in upgrading utilities to serve foreseeable mission requirements. For example, the General Services Area sewage pond was cleaned to provide adequate future capacity.

Proposed Facilities: The proposed Contained Firing Facility would meet the needs of active research and development programs and be environmentally desirable. The proposed fire station and medical facility are essential to provide modern on-site emergency services at this remote location.

Additional projects, such as more storage magazines and a modernization of production facilities, will be submitted to support the ability to produce high explosive weapons components. 


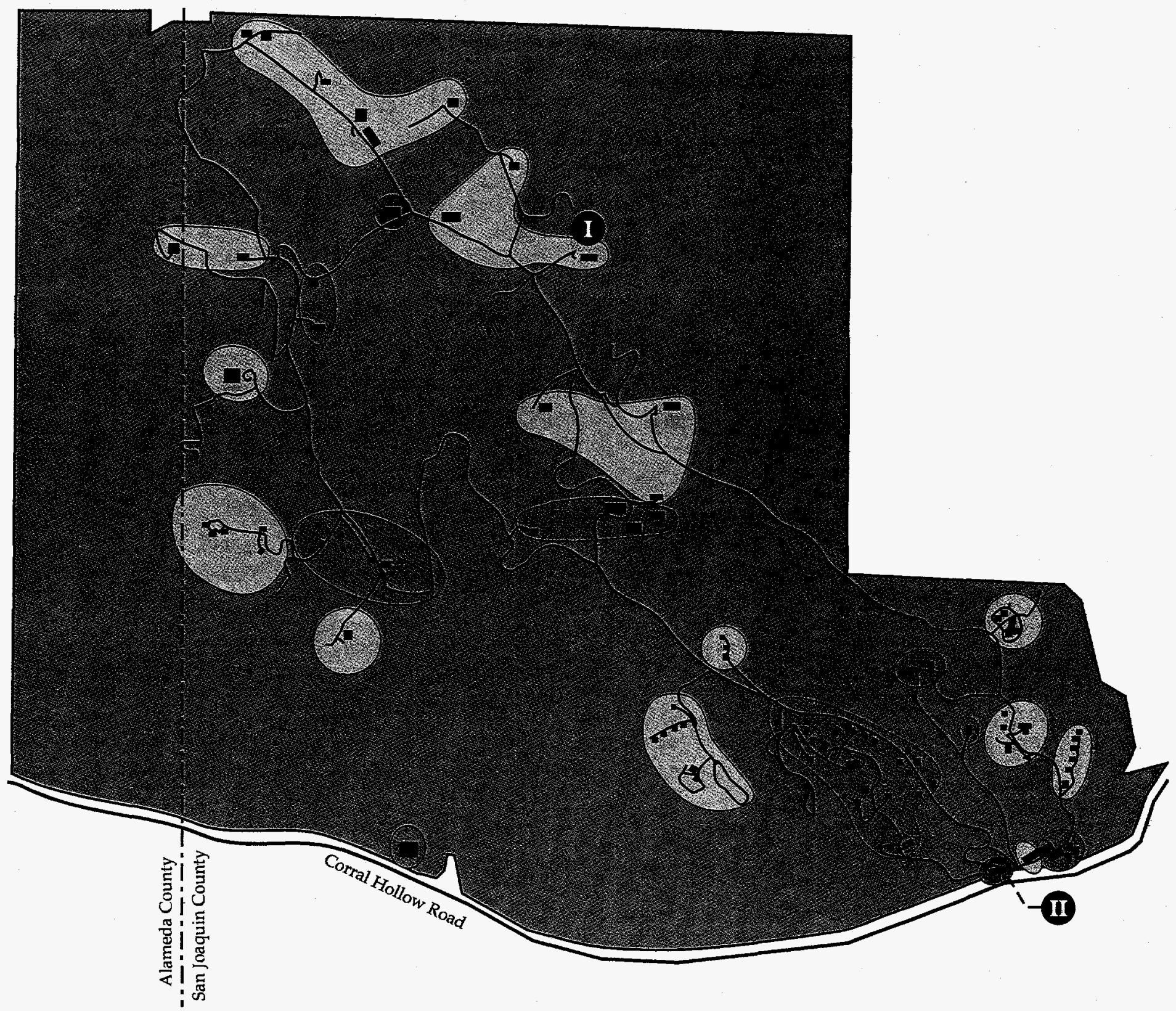

Construction Plan Project Summary

\section{Project}

Key

Funded Line-item Projects:

$\begin{array}{llll}\text { - } & \text { Site 300 Facilities Revit. Proj., Phase I } & 90 & 27.4 \\ \text { I } & \text { Site 300 Contained Firing Facility } & 96 & 49.7\end{array}$

Proposed Line-item Projects:

II Fire Station and Medical Facility

98

5.4

- Sitewide project

Notes: 1) Coordinated with Capital Assets Management Process (CAMP), as of 4/10/95 2) TEC is Total Estimated Cost
Land Use Legend

Industrial

Institutional (public and quasi-public facilities and collaborative)

Research \& Development and Administrative/ Technical Support

Undeveloped

140 Hectares (100 Acre)

Parcel

Equivalent

Figure 3. Site 300 Future Land Use/Master Plan Map. 
0

-

-

-

-

0

-

- 